\title{
Growth Dynamics of Three Trout Species (Oncorhynchus mykiss, Salvelinus fontinalis and Salvelinus alpinus), in Accordance with Environmental Parameters
}

\author{
Daniel COCAN*, Vioara MIREŞAN, Alexandru SAVA, Camelia RĂDUCU, Radu CONSTANTINESCU, \\ Andrada IHUT,, Aurelia COROIAN, Luisa ANDRONIE \\ Faculty of Animal Science and Biotechnologies, University of Agricultural Sciences and Veterinary \\ Medicine, 3-5 Mănăștur Street, 400372 Cluj-Napoca, Romania \\ *Corresponding author, email: cocandaniel@yaho.com \\ Bulletin UASVM Animal Science and Biotechnologies 71(2) / 2014, \\ Print ISSN 1843-5262; Electronic ISSN 1843-536X \\ DOI:10.15835/buasvmcn-asb: 10789
}

\begin{abstract}
In the context of increase the fish farms productivity and diversification of aquaculture products, have been evaluated the growth dynamics of three species of trout: rainbow trout (Oncorhynchus mykiss), brook trout (Salvelinus fontinalis) and arctic charr (Salvelinus alpinus). All three species of trout were grown in Trecătoarea Ursului trout farm, Braşov County and have benefited from the same environmental parameters and the same feeding conditions. The growth dynamics of rainbow trout was significantly higher, compared to the other two species. This is the result of domestication and improvement of rainbow trout, as well as its genetic characters. The lower growth dynamics of brook trout and arctic charr increase the production price, this aspect having directly implications on the selling price.
\end{abstract}

Keywords: trout species, growth dynamics, environmental parameters

Introduction. In time and space, interactions between genotype and environment, led to the most varied and amazing adaptations. For fish life, for growth and development, the primary goal of farming systems is all water features, including the biological and physiochemical characteristics. Environmental parameters of water have a different influence in growth dynamics of various species of trout (Moogouei et al., 2010; Blair et al., 2013).

Aims and objectives. According with the environmental parameters of water from "Trecătoarea Ursului" trout farm, we wanted to determine the growth dynamics of three species of trout (Oncorhynchus mykiss, Salvelinus fontinalis and Salvelinus alpinus), these having different environmental requirements.

Materials and methods. All three trout species studied are usually reared in "Trecătoarea
Ursului" trout farm and benefit from the same environmental parameters. Feeding frequency and feed used are the same. During the production cycles, from each species were monitored and measured 100 trout. Growth dynamics was determined based on the growth indices (total gain TG and daily growth gain DGG).

Results and discussion. Water temperature in "Trecătoarea Ursului" trout farm, does not exceed $13^{\circ} \mathrm{C}$ (August 2013), the minimum recorded for the same year was $1.5^{\circ} \mathrm{C}$. Mean water temperature for 2013 was $6.25^{\circ} \mathrm{C}(\mathrm{Tab} .1)$. These values are at the lower limit in terms of the biological requirements of rainbow trout (Moogouei et al., 2010), but at the same time, are optimal for raising trout from the Salvelinus genus.

In condition of these trout farm, to reach at commercial size, rainbow trout (Oncorhynchus mykiss) needs 14 months, brook trout (Salvelinus 
Tab. 1. The mean values of environmental parameters of water in Trecătoarea Ursului trout farm, Braşov County (2013)

\begin{tabular}{|c|c|c|c|c|c|c|c|c|c|c|c|c|}
\hline \multicolumn{13}{|c|}{ Month } \\
\hline Parameters & $\overline{\mathrm{Jan}}$ & Feb & Mar & Apr & May & Jun & Jul & Aug & Sep & Oct & Nov & Dec \\
\hline $\mathrm{T}\left({ }^{\circ} \mathrm{C}\right)$ & 2.00 & 2.00 & 3.00 & 5.70 & 6.50 & 9.00 & 10.50 & 13.00 & 12.00 & 6.30 & 3.50 & 1.50 \\
\hline DO (mg/L) & 10.10 & 9.90 & 9.40 & 9.20 & 9.00 & 8.90 & 8.70 & 8.40 & 8.60 & 8.80 & 9.10 & 9.60 \\
\hline $\mathrm{pH}$ & 6.70 & 7.00 & 7.0 & 7.10 & 7.10 & 7.20 & 7.20 & 7.20 & 7.10 & 7.00 & 6.90 & 6.80 \\
\hline
\end{tabular}

Note: T - temperature; D0 - dissolved oxygen.

Tab. 2. The mean values of growth indices (Tg and Adg) of the three trout species from Trecătoarea Ursului trout farm, Brașov County (2013)

\begin{tabular}{|c|c|c|c|c|c|}
\hline Specification & Species & Day & MU & $\mathbf{n}$ & $\mathbf{X}$ \\
\hline \multirow{3}{*}{$\begin{array}{l}\text { Initial weight } \\
\text { Iw }\end{array}$} & Oncorhynchus mykiss & 420 & $\mathrm{~g}$ & 100 & 0.05 \\
\hline & Salvelinus fontinalis & 480 & $\mathrm{~g}$ & 100 & 0.04 \\
\hline & Salvelinus alpinus & 720 & $\mathrm{~g}$ & 100 & 0.06 \\
\hline \multirow{3}{*}{$\begin{array}{c}\text { Final weight } \\
\text { FW }\end{array}$} & Oncorhynchus mykiss & 420 & $\mathrm{~g}$ & 100 & 266.70 \\
\hline & Salvelinus fontinalis & 480 & $\mathrm{~g}$ & 100 & 271.30 \\
\hline & Salvelinus alpinus & 720 & $\mathrm{~g}$ & 100 & 252.44 \\
\hline \multirow{3}{*}{$\begin{array}{c}\text { Total gain } \\
\mathrm{Tg}\end{array}$} & Oncorhynchus mykiss & 420 & $\mathrm{~g}$ & 100 & 266.65 \\
\hline & Salvelinus fontinalis & 480 & $\mathrm{~g}$ & 100 & 271.26 \\
\hline & Salvelinus alpinus & 720 & $\mathrm{~g}$ & 100 & 252.38 \\
\hline \multirow{3}{*}{$\begin{array}{l}\text { Average daily gain } \\
\text { Adg }\end{array}$} & Oncorhynchus mykiss & 420 & g/day & 100 & 0.6348 \\
\hline & Salvelinus fontinalis & 480 & g/day & 100 & 0.5651 \\
\hline & Salvelinus alpinus & 720 & g/day & 100 & 0.3505 \\
\hline
\end{tabular}

Fig. 1. Growth dynamics of the three species of trout reared in Trecătoarea Ursului trout farm, Braşov County (g/month)

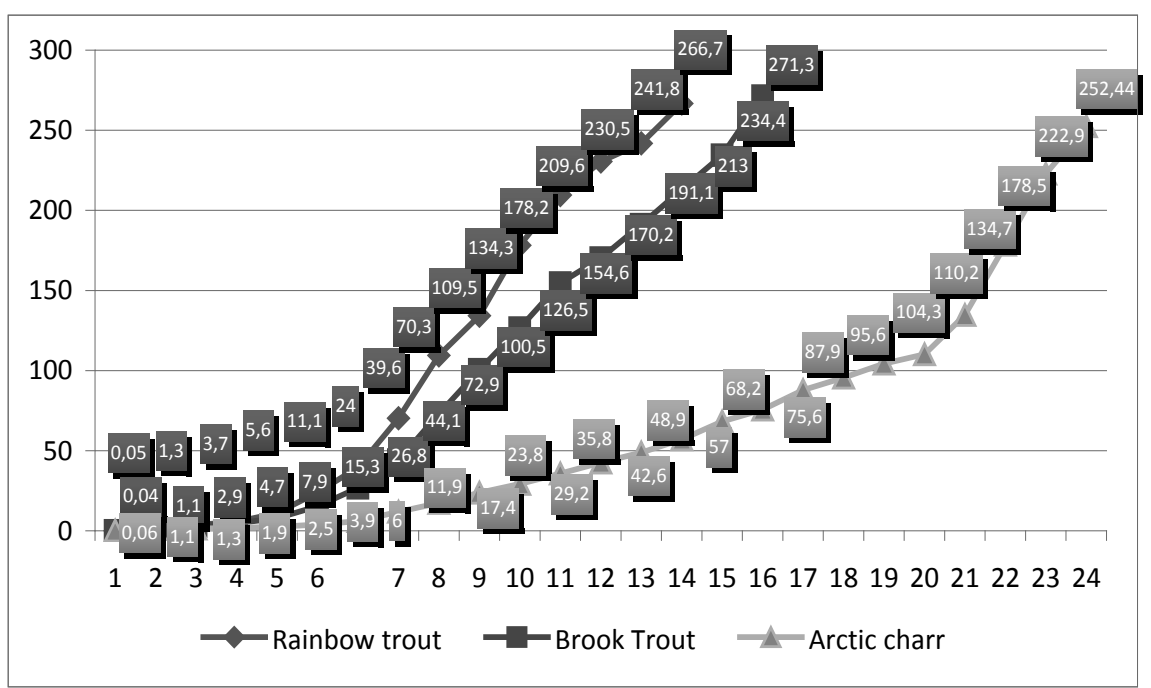

fontinalis) needs 16 months, and arctic char (Salvelinus alpinus) needs 24 months (Fig. 1).

Regarding the total gain, it was $266.65 \mathrm{~g}$ in rainbow trout; brook trout - $271.26 \mathrm{~g}$; and for alpine trout $-252.38 \mathrm{~g}$. Daily growth gain recorded in the three trout species was as follows: rainbow trout $=0.6348 \mathrm{~g}$; brook trout $=0.5651 \mathrm{~g}$; arctic char $=0.3505 \mathrm{~g}($ Tab. 2).

Conclusion. Rainbow trout demonstrates a great plasticity compared with other two species. This species had the best growth dynamics, regardless of environmental conditions.

\section{REFERENCES}

1. Moogouei R, Karbassi AR, Monavari SM, Rabani M, Taheri Mirghaed A (2010). Effect of the selected physico-chemical parameters on growth of rainbow trout (Oncorhynchus mykiss) in raceway system in Iran. Iranian Journal of Fisheries Sciences, 9(2): 245-254

2. Blair JM, Ostrovsky I, Hicks BJ, Pitkethley RJ, Scholes P (2013). Growth of rainbow trout (Oncorhynchus mykiss) in warm-temperate lakes: implications for environmental change. Canadian Journal of Fisheries and Aquatic Sciences, 70(5): 815-823. 